INVITED 2013 CARROLL D. Clark LeCTURER

AT THE

UNIVERSITY OF KANSAS 



\title{
INTERVIEW WITH ROBERT WUTHNOW
}

\section{INTERVIEW CONDUCTED BY:}

\author{
DANNY ALVORD \\ University of Kansas \\ KEVIN MCCANNON \\ University of Kansas
}

\begin{abstract}
Dr. Robert Wuthnow is the Gerhardt-Andlinger 52 professor of Sociology at Princeton University. His works focus on social and cultural change. His work has appeared in the top journals of sociology, and he is the author of several books and edited volumes, such as The Consciousness Reformation, Small Town America, The Structuring of American Religion, After the Baby Boomers, and many more. Dr. Wuthnow joined us to discuss his book, Red State Religion: Faith and Politics in America's Heartland.
\end{abstract}

ALVORD: Robert Wuthnow, thank you so much for joining us today. I really, really appreciate it. You've written so prolifically on such a wide range of topics: religion, politics, and small towns. But to start with, I'm sort of interested to hear how you would describe your sociology: what are the main themes that sort of connect everything that you do?

WUTHNOW: Well I think it's understanding one theme that runs from the beginning to now, over a number of years, it would be an interest in social change. That, of course, is pretty abstract and it leads into a number of different topics, but I remember distinctly as a graduate student at Berkeley, when I first kind of realized that I was interested in social change. I was in a class with Charles Glock, and he was interested in social change. And I remember that he drew a line on the blackboard, a sloping line, with a question mark on it, "Is this society changing for the better, or for the worse?" He was certainly convinced that it was changing. Me, having just arrived in Berkeley from Kansas, I knew what he was 
talking about. I had a sense that things were changing. At least they were for me. And so, not to spell out the whole trajectory, but I got interested in changes that were happening in the ' 60 s to some extent, 1970s, so forth, having to do with reactions to the Vietnam War, counterculture on campus, changes in religion, spirituality, new religious movements. And then, kind of took a long detour for ten years or so writing a book based on European history over four centuries (so that was certainly on social change). Then I came back to the US as a focus, looking at the development of the religious right, changes in religion, that I call the restructuring of religion. And then more recently, I've been really focusing on how common people, ordinary people, people whose voices rarely make it into the media, are experiencing change in their communities. In terms of smaller communities, Midwestern communities, many of those communities are declining in population, so they are confronting that, and other communities, such as certainly some of the ones between here and Kansas City, are growing rapidly, so they are experiencing a different kind of change.

ALVORD: So you touched on it a little bit, but in what other ways does your biography play into the development of what you became interested in?

WUTHNOW: Well, yes, as I mentioned, my biography, I mentioned that I had been a student here at KU before going to Berkeley as a graduate student, but I was raised in a very small community, a rural farming community out in the middle of Kansas. And frankly, for about the first twenty years of my life I figured that's where I would spend all of my life. Had it not been for the fact that my father died when I was a freshman in college, I probably would've done that. I would have found something to do so that I can go back and be close to my parents and live in a small town. When it became evident to me that that was just out of the question, I spent most of my time here at KU trying to figure out what on earth I was going to do. And finally, I remember watching a professor one day pacing back and forth in front of the class and lecturing from his notes and a light bulb went on in my head and I said, "I could do that!" So I was then kind of drawn into the social sciences, I didn't know which one, but I finally realized that 
sociology was one that was possible to get into without too much advanced preparation. And it was also just wildly interesting in terms of the topics that one could study. So over the years, yes, I have focused mostly on sociology of religion, but I kind of fell into that almost by accident because that's not what I had planned to focus on in graduate school. I started out thinking I was going to focus on organizations, and that didn't work out. Then I wrote a dissertation proposal on race, prejudice, and did some early work on anti-Semitism. Then suddenly, some professors at Berkeley got a grant to work on religious movements and asked me to be part of that project. So I did, and I kind of meandered over the next several decades from occasionally studying religion topics and then just as often studying other things. So I have been personally interested in religion, my parents were quite interested in religion, so much so that they argued over the dinner table about it, a lot, and at times when I was getting bored with religion and thinking, "Well, certainly nobody in the American Sociological Association gives a whip about it," then all of a sudden something would happen, like the Jonestown mass suicide. So everybody [asked] "Why is that possible? How do people do that?" And Jerry Falwell comes on the scene, and the Iranian Revolution happens, and suddenly you have conservative Islamic leaders in international policy affairs. So from time to time, it's almost been events in the outside world that have called my attention back to studying religion and posing questions that I was trying to answer and find some way about what's going on with religion, politics, and society.

MCCANNON: Why the historical approach?

WUTHNOW: Well, yes, that's a good question. Partly because an interest in social change necessarily implies paying attention to some sweep of history-maybe a fairly short sweep, if one's studying social movements. For my dissertation, which was then published as a book called The Consciousness Reformation, there was a lot of interest in it. It was based on an original survey, but there was also this interest of mine and among my committee, in trying to understand things like secularization. So, even if churchgoing is holding stable, is it possible that people don't think about the world, and the events that shape the world in terms of 
divine intervention in some way, as they might have. Another longer-term change in that project was individualism, American individualism. So to understand why people now were individualistic, and why some of them were rejecting that, I found it necessary to go back to the Horatio Alger stories, the late nineteenth century. So that was kind of an early interest in historical topics. One of my advisors at Berkeley, kind of a peripheral advisor but he was certainly there, was Robert Bellah. Bellah at the time was working on civil religion, and he was in the process of writing his book on the broken covenant, that was a historical sweep of American civil religion. And, after that, then what really got me interested in long-term history, the European history project was the rise of interest among sociologists in world systems theory from Emmanuel Wallerstein's publication of his first volume in that series in 1974, if I remember right. I that interest in world systems theory in sociology was part of a reaction against modernization theory. It was also related to the political turmoil of the period. A lot of the 1968 uprisings, in various places throughout the world, it was also related to an increasing interest I think in sociology, in political sociology, I'm thinking especially of Theda Skocpol's States and Social Revolutions, that I was very impressed with at the time. So even though I was not a historian, I wasn't trained as a historian, I didn't have some of the language skills that I needed, I decided it would be interesting and if nothing else educational to me, to tackle some big questions about how something as major in terms of a cultural shift, and I was thinking of myself as a cultural sociologist, a cultural development as major as the protestant reformation, how was that influenced by changes in the political economy of Europe at the time? What sort of changes, especially in the relative balance of power between agrarian elites and mercantile elites, were opening up spaces for new ideas? And then put that in a comparative perspective in addition to across nation states, then to compare it with the enlightenment to see if there were any similar kind of processes in political economy, and then also, [with] that project move it forward to the rise of European socialism and see how that worked. So that was a hugely intensive investment. labor-intensive project, of intensive reading that took about ten years to work on that book. 
Frankly exhausting to do something like that, and I guess I probably concluded "never again."

So I've worked on more manageable projects since then. And so then coming back to working on US topics. Some of these recent ones, those have partly been inspired because I find historical reading fascinating. I enjoy looking through archives and finding letters, memoirs, and digging up old newspapers, and going around to historical societies. And I've also been very fortunate teaching at Princeton, to have excellent colleagues in the history department and the religion department who knew what they were doing - the history - much more so than I did. As I would look across the street and talk to them and think about what they were doing, they were often doing such interesting things. The topics, frankly, were more interesting than a lot of the boring things that we as sociologists do, so that was another impetus.

ALVORD: So, hearing you talk about your meanderings, I guess, through sociology, you're dropping the most influential pivots, I guess. How big changes in the discipline affected you specifically. So I guess I'm wondering, how have you seen the discipline change?

WUTHNOW: Yes, how have I seen the discipline change? Well, big question. So when I very first began thinking about going to graduate school in sociology, this was in the late 1960 s, and not having majored in sociology, (I didn't know very much about it) so to just kind of take that as a benchmark to think about some of the changes sense then. Because I hadn't majored in sociology and didn't know anybody in sociology really, I wrote letters to a few people, and I also happened to meet someone through a friend here in Lawrence who had recently finished her $\mathrm{PhD}$ at Wisconsin, maybe she was still there, so I remember that conversation. There were a few others. And my question was, “Okay, I don't know very much about sociology, I've read Durkheim on my own, Weber on my own, a few other things. What should I read? I've got some time this summer, what should I read?" Their advice was, "Talcott Parsons. You've got to read Talcott Parsons. He's the guy." I spent a lot of the summer reading everything that Talcott Parsons had written up to that point. And it turned out that that was not wasted 
time. I was then faced with the decision: should I go to Berkeley or should I go to Harvard? Parsons was still at Harvard, but Harvard, even at that time, looked like a very boring place, whereas Berkeley looked like a much more interesting place. And so I wound up taking my theory required courses with Neil Smelser, who was a student of Talcott Parsons, and so we heard a lot about Talcott Parsons in the general theory course and then there was a special seminar, actually on Parsons' theory itself. So take that as a starting point, and certainly recognize that even at that time-and certainly over the next decade-there was this huge reaction against Parsons and everything that Parsons stood for. The four fold boxes, and the systematic theory, and the social evolution, societal evolution stuff. The only way that that retained an interest for me because of Bellah, who as I mentioned before, was there. I took a class from him and he was also a student of Parsons. So he had written a little short essay on religious evolution, included quite a bit of that in his course and recently, in the last ten years after he retired, returned to it and wrote a huge book that was published before he died on religious evolution. But being at Berkeley, even though it was a very good department then, as it is now, being there in the late sixties into the mid-seventies, there was much less attention on anybody's part to what was happening in the discipline of sociology, than was what was happening on the streets, and on campus. I mean, I lived a block from Black Panther headquarters; I frequently circumvented clouds of teargas to get to the sociology department; I was there during people's park strike, the third world strike, the counterculture shutdown, all of those things. So those of us of my cohort who were experiencing what was going on in the society at that time, and then either dropping out, as some did, or returning to sociology, that was an impetus for a lot of people to be interested in social movements, social change, and political sociology. Theda Skocpol is about my cohort at Berkeley, Ann Swidler, Jeff Alexander, Erik Olin Wright were all in the same classes I was. So it was a kind of an exciting time of change.

Moving forward, my view at least, is that the discipline expanded for a while to take account of some of those very practical human interests. It expanded to be more inclusive, certainly in terms of interest in gender, race, sexual orientation, and 
international comparative issues. And then at some point, the discipline also contracted. And at this point, I think there's actually quite considerable division in the discipline at large between those who want to erect high walls around the discipline and say that it should be rather narrowly confined to a certain kind of neopositivist methodology (probably quantitative), emulating the sciences, taking seriously the idea of replication, proof, and prediction, hypothesis testing... versus others in the discipline who are still a little bit more inclusive and more interested in the policy or at least the practical application of sociological research.

ALVORD: In your book, Red State Religion, you're making the argument that red state religion and red state politics that we see today have a long and complicated history. You're using specifically Kansas and Texas, although, it sounds like Texas is going to be more explored in your next book. So why Kansas and Texas, and how general do you intend the term "red state religion" or "red state politics" to be applicable outside of Kansas and Texas?

WUTHNOW: Well my interest in Red State Religion began some years ago with a broader interest with the religious right and the growth of religious conservatism connected to political conservatism starting in the late 1970s with the moral majority, and with Ronald Reagan, Jerry Falwell, Pat Robertson, that whole tradition of religious right leadership that's been studied a lot. My reason for then eventually coming back to that topic and focusing on Kansas was of course partly autobiographical. But I thought it was also a valuable potential case study to understand both over a longer historical period what might be happening that led up to the religious right in the $1980 \mathrm{~s}$, and as a more specific case study, making it possible to look at local conditions, and then how those local conditions influenced county and state politics. My reason for choosing Kansas was that Kansas has been Republican-maybe moderate Republican, progressive Republican, but it has been Republican over a longer period by a wider margin more than any other state. So it's kind of an interesting case study of looking at the extreme case and saying, "Okay, in recent years, Kansas has been controversial because of textbook controversies, that 
evolution/intelligent design, and so forth. It's been controversial because of massive anti-abortion protests, controversial because of the constitutional ban of same-sex marriage, and a whole variety of things.

So that poses the question, "Is all of this somehow new? Does it contradict something earlier in Kansas' history?" Which, in simplistic terms, is what Thomas Frank argued in his widely-read book What's the Matter with Kansas? And I frankly didn't know. When I began to think about Kansas, I vaguely remembered from seventh-grade Kansas history that the Wyandotte Constitution of 1859 had included a prohibition clause. It didn't pass, but it almost did. And the temperance movement was very strong from the very beginning. So I thought, "Well, maybe I'm going to find a story that's one-thing-lead-to-another." It's a conservative state now; it's always been a conservative state. But then as I began seeing that women's suffrage, for instance, was a very important movement in Kansas in the 1860 s, and populism was a very important movement in the $1890 \mathrm{~s}$, and that began to complicate the picture. And I realized, "Well, I really want to just look closely at the whole 150year history, and not try to make any single, sound bite, sweeping generalization about it, but to say, you know, from decade to decade, here are some of the things that changed. And I finally wound up making an argument about the recent prominence of the religious right that in some ways was similar to what I had written earlier about the national rise of the religious right. But in Kansas, it was really much more important to look at who had moved into the state, especially the massive influx of Southern Baptists starting in World War II, then really picking up in the 1960s. So that there were just large numbers of Southern Baptists in Kansas, where there had never been any before. They were coming in from Oklahoma, Arkansas, Texas, and Missouri. They were much more conservative and became more active politically than a lot of other groups had.

Then the other big change was that after Roe v. Wade in 1973, the large population of Catholics in Kansas that had always leaned towards more Democratic candidates switched, and they began supporting conservative Republican candidates. So between their support, and the support of conservative Southern Baptists, who were also voting for conservative Republican candidates, as well as 
some independent megachurches that were capable of mobilizing against abortion or whatever it was, over the period of twenty years or so there was this huge religiously conservative coalition of sorts supporting conservative candidates in Kansas. So having finished that, I've also always kind of just vaguely interested in Texas, I thought, "Well, it would be interesting, since Kansas was historically Republican and Kansas was a free state, against slavery and a whole variety of things, what about Texas?" Because one of the things that was clear about Kansas, even though there aren't many African Americans in the population in Kansas, race is very important. And in recent years, Latino immigration has been very important in Kansas. So I thought Texas would be ideal because it is in the south, because it did have a history of slavery, because over most of its history it voted for Democratic candidates (although more recently, Republican candidates), has a large African American population, has a large and growing Latino population.

ALVORD: At the beginning of your book, you raise a pretty interesting paradox. It's why, how, and under what conditions have states that have traditionally had a pretty strong separation of church and state, how did religion and politics mix so much? And you point to two specific turning points: the 1920s, with prohibition and specifically, the election of 1928; and also 1964, which you really seem to stress. I was wondering if you could talk a little bit about what was happening during those times that what allowed for religion and politics to mix in such a unique way.

WUTHNOW: So in 1928, the mobilizing factor that brought a lot of Protestant clergy into the political arena as mobilizers and activists was the candidacy of Al Smith, as a Catholic democrat. Their concerns about him in Kansas were partly because he was a democrat and partly because he was from New York, but also because he was a Catholic. And as I said before, Catholics in Kansas had always voted democratic for the most part. Catholics, for geological reasons and ethnic reasons, had never been very keen on prohibition. So the fear of these Kansas Protestant clergy - and this is true of Texas, too, Protestant clergy there-was if Al Smith was elected, prohibition would be repealed-which it 
was in 1933, but they were already concerned about that, or that it wouldn't be enforced. That was almost as much of a concern; that is what mobilized Carrie Nation, she thought it just wasn't being enforced. So there was that, and there was also this longstanding fear of Protestants that Rome and Catholics and so forth and the Vatican were trying to take over and turn the American government into a theocracy of some kind and pay homage to the Pope, all these things. So they considered it a matter of religious freedom, among other things, to get involved in politics to protect their religious freedom, as they said. So that was the part of separation between church and state that could be interpreted that way. Yeah, you don't want any church to become a political establishment, and so maybe you vote for somebody or organize movements to oppose that. At any rate, that whole phenomenon centered around 1928 created a precedent for people who otherwise might not have considered it appropriate to bring religion into politics to do so.

Then moving forward to 1964 , the issues were really rather different. In 1964, it was partly-this was Goldwater against LBJ-and Goldwater didn't do very well at all, in the final analysis. But Johnson, of course, had come in after the assassination of Kennedy, with the intention, even though he was a Texan, a Democrat, of passing the civil rights legislation that had been advocated for civil rights movement at that point and probably would have been passed by Kennedy if had not been assassinated. And so there was a reaction among some of the white clergy just against desegregation and racial inclusion and civil rights. But what surprised me was the extent to which moral politics, just moral issues, became important. And those had partly to do with race, because there the moral argument was, "Oh, look at all these terrible, immoral civil rights demonstrators who were breaking the law. We can't trust them. They're just not the kind of people we want in America." But it also had to do with the sexual revolution, which was already starting. Pills were legalized in 1961 or 2. It also had to do with the baby boomers coming of age and the older generation looking at them and seeing that they're starting to dress in miniskirts and going to dances and listening to rock and roll, and all these terrible things. And so it was Billy Graham, who was out there having his massive crusades and preaching against 
moral decay. In 1963, 1964, there was Ronald Reagan, campaigning for Goldwater, talking about moral excesses of big government and wasteful welfare spending. And one of the more interesting episodes related to 1964, there was the Walter Jenkins episode. Jenkins had a homosexual encounter, who was an aid of Johnson. One of the more interesting broader developments was the organization of a movement called "Mothers for a Moral America." They were actually be organized by some of Goldwater's staff. Some of Goldwater's staff produced a thirtyminute film that was to be aired right before the election on Goldwater's behalf, that basically suggested that because of Johnson, and everything that was going on, America was going to hell in a hand basket, in terms of morality. It starts out with a picture of a careening black limousine, that made you think maybe that's Johnson with a beer bottle flying out the window that's careening down the road. And it flips over to riots in the street, and it even includes some censored photos of strip clubs and nude dancing, I mean it was just totally over-the-top. And then it lines up with somebody, I forget another actor, might be... I don't remember who it is, but somebody who has a big rifle on the wall behind them, and saying "We good people have to be trustworthy citizens, and moral, and all this." Anyway, it was so over-the-top that Goldwater, when he first saw it, he was campaigning in Philadelphia at the time, he said, "No. We absolutely cannot do this." Especially because they were just racist themes all the way through it. So no, we can't do it. Mothers for a Moral America got ahold of it and they distributed it all over the country in churches! And so that certainly mobilized a lot of conservative churches, Protestants, especially. But interestingly enough, on the other side, and this was with respect more specifically to the Jenkins controversy, some of the most prominent theologians including Paul Tillich and Reinhold Niebuhr, and Abraham Heschel, several others, came out in favor of Johnson and said, “Johnson's doing the right thing; civil rights is way more important than these kind of petty moral issues."

So at any rate, all of that actually became a starting point, especially as the Goldwater supporters just went away licking their wounds, thinking, "What can we do?" And a number of them retrenched, dug in, figured out, "Okay, what do we need to do?" 
And Ronald Reagan happened to be one of them, and so we can see that moving forward into the religious right. One other thing about this issue of moral politics more recently... what happens now, and I've seen this more in Texas project than in Kansas, at least thinking about it in Texas, is the conservative preachers will say it's okay to talk about politics, a certain kind of politics, even from the pulpit, and even, for that matter, to implicitly endorse certain candidates, because they see all that through moral terms. Which they say, "Oh, that's what we should be about. We should be talking about that." So they focus on, usually, one or two issues: abortion, usually, or marriage equality, or in some cases, Obamacare, or whatever it might be. And so what they do, whether they realize it or not, is that they advocate for voting Republican. So the people in their churches, whether they happen to be white churches, you can imagine, whether they happen to be upscale, college-educated people, or downscaled people, who in Texas are called "the Bubba voters," vote Republican. And because that constituency of white Anglican voters is shrinking, what you need is a high turnout and a higher percentage for Republican candidates, which those moral and social issues help to provide. So then if you ask those preachers-which we've done- "Do you favor helping the poor?" "Oh yes, certainly, we do." "Are you a racist?" We don't ask it that way, but we try to find out, and no, no they certainly are not, and they maybe aren't even against immigrants or whatever. So inadvertently by supporting those certain moral political issues, which therefore give the Republicans a winning majority all the time, they have essentially disenfranchised the poor and minorities, and made sure that none of the social welfare programs that those people need ever get passed... and that the Democratic candidates that those people are more likely to support never win. That's the kind of red state phenomenon. I don't know if this applies very broadly, if we go back to your original question. If one studied Iowa, or Indiana, or in recent years, Oklahoma, or even Ohio, I think some of the same things apply, but I'm also convinced that state and local politics matter so much that one has to take account of the differences in the configuration, the population, and also the history of those different locations. 
ALVORD: It's so interesting. So it sounds like it was... are you able to make a causal claim, I guess is what I'm trying to say. Was it religion getting into politics? Then, the politicians were savvy and said, "Hey we can use this." Or are you able to make a causal claim?

WUTHNOW: No, not really. You can't make any kind of direct, linear causal claim. You can see causality working in both directions at different times. And in Kansas' history, that's certainly the case. You can see times when it looks like religion and politics are mixing, and they're not. Other times when it looks like the political leaders are kind of making use of the religious leaders, and other times the reverse is happening. That said, I suppose of it looking like religion and politics are really mingling is the story that I start the book with, which is the story of Abraham Lincoln coming to Atchison, Kansas in 1859 and speaking in a Methodist Church. While the Methodist leaders where quite excited to have him, it turns out that the Baptist leaders (that was kind of the second-largest group in Atchison) probably would not have had him because they were mixed as far as slavery was concerned. Some of them were for it; some of them were against it. But the real reason Lincoln spoke in a Methodist church was that it was the only large hall available, so it would hold 350 people or so, and so that made sense. The Baptist church was about a month away from being completed, and it was nicer and it was larger, so if it had happened a month later it might have happened in the Baptist church. And when he went on to Leavenworth, they had a big public hall of some kind so he didn't speak in a church there at all.

The same thing later on with the suffragists: Susan B. Anthony, Lucy Stone, speaking in Methodist churches as well as they traveled around the state. In small towns, that's usually the only place there was to meet. So if anybody benefited in those early years, it was often that the clergy or a particular church congregation even might benefit just from the publicity of having somebody certainly like Lincoln come and speak or later on, many temperates leaders, many governors spoke in churches. And so what you see there, which I think is still true in many cases, is you have a political leader who is sincerely a person of faith, Protestant 
or Catholic, maybe they have been involved themselves in church work, as Governor Allen in Kansas history, was an example. Maybe they are quieter about their own faith, as Governor Capper was. Maybe they are much more outspoken about it, as the current Governor Brownback is, or in Texas, Rick Perry. And so in those instances, the personal faith means that the political leader can sincerely go to certain meetings, say certain biblical things, pray, invoke God's blessings, all of those things, and at the same time, know that it's not going to hurt the political cause either because there is a lot people out there who value that, who think that it's great. It's a little harder to identify the exact religious connections currently with the Tea Party than it was earlier with the prolife movement. That's because the Tea Party's primary emphasis is fiscal conservatism, and so what on earth about religion or theology would lead one to believe in fiscal conservatism. It turns out there are a bunch of arguments... but for any of those arguments it's just as easy to find counterarguments. So that's why people who are studying the Tea Party note that there are a lot of religious people involved with it. The question is still open as to whether they still happen to be there because they were already mobilized for conservative causes-because of abortion and marriage equality — or are they there because they actually thought through the issues?

That's the unanswered question about the Tea Party, I think.

ALVORD: A final question: what kind of lessons do you want people — not just academics, but anybody — to take away from your study, your Red State Religion book?

WUTHNOW: Well, I thought about that a lot. I even thought it would be interesting at some point to write a short essay titled, "What I Learned in Kansas." One of the things I would certainly stress (assuming the audience we are speaking about is sociologists, broadly defined, rather than the general public) I would emphasize paying attention to stories, to narratives. There is a lot of interest in sociology in those. I would emphasize, if looking at any of these religious and political issues, the importance of local context, state context, if it has to do with politics at all. I would emphasize looking at the grassroots as far as 
possible - whether that's through stories, interviews, or whatever. Gender, then, becomes an issue especially for historical studies because so often leaders were men that you miss the women if you don't. A lot of the interesting grassroots stories come from women-you deal with gender, family, and children and so forth. I would also emphasize race, because race is such an important point of inflection in our culture that even people who are studying, let's say Korean-American churches are finding that notions of race and the history of race in our culture inflects those investigations. And finally, as a concept, a kind of narrow, specific, sociological concept, I would emphasize the idea of symbolic boundaries, which I began to look at a little bit back in the 1980s, in thinking about the restructuring of American religion, which my former colleague, Michéle Lamont, who is now at Harvard, has written about. My current colleague, Andreas Wimmer, who works on comparative ethnicity, has written very masterfully about beginning to understand more of the ways in which symbolic boundaries become salient at certain times, become politically effective, become related to differences in social networks, and then, because of various kinds of mobilization or even demographic changes, begin to be reconfigured and that is a kind of abstract concept. It's the one I've found most recurring in the Kansas project and the Texas project. The Texas book will have a long, boring final chapter that talks about that.

ALVORD: Well, it's absolutely fascinating and interesting, and you're fascinating and interesting, and I could just talk to you forever, but Robert Wuthnow, thank you so much for your time.

WUTHNOW: Thank you. 